\section{ESF warns of dangers of shortfall in posts for young scientists}

"THERE is a potentially dangerous situation in Europe which is causing young scientists who might otherwise choose a career in research not to do so," Sir Brian Flowers, president of the European Science Foundation (ESF), said last week. He was speaking after the ESF assembly had approved the annual report for 1978 .

A recent ESF study has shown that in most of its members' countries, "the majority of those now in employment will stay in office until the beginning of the 1990 s when they will reach their normal retirement age. The demand for replacements during the next 15 years will be exceedingly low." The annual report says available posts are now so few that the chance of a junior research assistant getting a permanent university appointment has gone down from $70 \%$ in the 1960 s to $15 \%$ this decade.

The problem of making posts available to young research workers is wellknown. The ESF draft report adds one extra argument. In the past, it says, $65 \%$ of a university's budget was spent on personnel and the remaining $35 \%$ on maintenance, administration, upkeep of the library and research. Now the share taken by salaries has increased, leaving less for the other activities including research.

The ESF does not suggest what should be done. For the present it merely points out the dangers and urges countries to find their own solution.

The assembly approved a budget of $3.996 \mathrm{~m}$ French francs for 1979. Among the activities it will finance are three new ones, two in the humanitiesByzantine and Chinese studies-and one covering the ESF's work in synchrotron radiation.

Ten member organisations are providing an additional 500,000 French francs for a feasibility study on building a European Synchrotron Radiation Facility. Such a machine would be distinguished from existing machines by its very high brightness, specially designed elements for each wavelength range, undulators which are very bright emitters and a beam time structure for time resolved studies. ESF hopes to complete its report within a year so a quick decision can be made whether to build the facility.

At the meeting of the Assembly, Sir Brian welcomed Dr John Goormaghtigh who takes over as Secretary-General from Dr F. Schneider in January 1980. Dr Goormaghtigh works in the social sciences.

Judy Redfearn

\title{
Wiesner attacks increasing government regulation of US university research
}

INCREASING attempts to regulate university research have led to floundering relationships between the federal government and the academic community that have reached a "point of crisis", according to Dr Jerome B. Wiesner, science adviser to President Kennedy and now president of the Massachusetts Institute of Technology.

Speaking at a conference of research administrators in Washington last week, Dr Wiesner said that this could seriously curtail the effectiveness of the nation's major research universities, and that the increasing intrusion of the federal government into university affairs threatened their capacity to produce innovative ideas.

He singled out for particular attack proposals published earlier this year by the Office of Management and Budget to introduce significant changes in the accounting procedures-currently listed in the so-called Circular 21-by which universities compute how much they should be reimbursed for the direct and indirect costs of carrying out federallysponsored research projects.

OMB has claimed that the revisions are aimed at rationalising the procedures used by different government agencies, and reducing the risks of the possible misuse of funds. Dr Wiesner, however, said that the proposed changes, which have been widely criticised by the research community, would weaken universities as institutions and reduce their capacity to conduct high quality research

"There is no question, for example, that they limit in a destructive way reimbursement for indirect costs that are necessary and essential. There is no question that a number of the proposals are inequitable or administratively impracticable or both."

$\mathrm{He}$ called on President Carter to defer implementation of the revisions until a full study of the current problems faced by university research workers had been completed. "The proposed revisions to A-2I not only sacrifice flexibility but, far more significantly, they move in the direction of viewing universities in the same manner as commercial organisations and away from the concept of a partnership between the universities and the federal government."

Dr Weisner also criticised the recent decision of Congress, in passing the National Science Foundation's budget for the fiscal year 1979 , to place a ceiling of $\$ 48,000$-the maximum rate payable to Government scientists-on the salaries of university research scientists receiving university support.

"What this means is that Congress is limiting the reimbursability of salaries of the best faculty, the stars, the Nobel Prize winners, those people who make our institutions great. Universities will have to make up the difference, starting with an already substantial impact, and that's only the beginning," he said.

David Dickson

\section{Few surprises in UNCSTD draft plan of action}

A DRAFT plan of action has been published by the secretariat of the United Nations Conference on Science and Technology for Development (UNCSTD), scheduled to take place in Vienna next August. The plan will be discussed by the UN General Assembly in New York next week, and a revised version will then be considered by the conference's preparatory committee when it meets at the beginning of next year.

There are few surprises in the draft plan, which is essentially a synthesis of the various proposals made in the national and regional papers which have already been submitteed to the secretariat (a number of countriesperhaps most noticeably the United States-have yet to complete their national papers).

The draft plan of action has reduced the proposals to 201 separate recommendations grouped into two main sections: science and technology for development, and "institutional arrangements and new forms of international co-operation in the application of science and technology."

Popular themes include the need for codes of conduct covering both the transfer of technology and the behaviour of multinational companies, the need to improve scientific and technological information services and policy-making machineries, and concern about the effect of the "braindrain" to developed countries. There are also suggestions for encouraging cooperation in research between developing countries, and ways of re-orienting educational systems towards national needs; and several countries ask for an emphasis on the development of appropriate technologies.

Other suggestions range from the proposal that developed countries set aside $0.5 \%$ of their gross national product for research related to Third World issues, to the suggestion that 